\title{
Lack of evidence for the presence of Schmallenberg virus in mosquitoes in Germany, 2011
}

Kerstin Wernike ${ }^{1 \dagger}$, Hanna Jöst ${ }^{2,3+}$, Norbert Becker $^{4}$, Jonas Schmidt-Chanasit ${ }^{2,3}$ and Martin Beer ${ }^{1 *}$

\begin{abstract}
Background: In 2011, a novel orthobunyavirus of the Simbu serogroup was discovered near the German-Dutch border and named Schmallenberg virus (SBV). So far, SBV genome has been detected in various field-collected Culicoides species; however, other members of the Simbu serogroup are also transmitted by mosquitoes.
\end{abstract}

Findings: In the present study, approximately 50,000 mosquitoes of various species were collected during summer and early autumn 2011 in Germany. None of them tested positive in an SBV-specific real-time PCR.

Conclusions: The absence of SBV in mosquitoes caught in 2011 in Germany suggests that they play no or only a negligible role in the spread of the disease.

Keywords: Schmallenberg virus, Orthobunyavirus, Arbovirus, Vector, Mosquito, Transmission

\section{Findings}

Introduction

Schmallenberg virus (SBV), the first European member of the Simbu serogroup, genus Orthobunyavirus, emerged in summer 2011 near the German/Dutch border [1]. Since then, the virus has spread very rapidly over large parts of the continent. Affected adult ruminants show either no or non-specific, mild clinical signs for only a few days, but fetal infection may lead to severe malformation, stillbirth or premature birth [2].

Simbu serogroup viruses have been frequently isolated from Culicoides midges, but also from mosquitoes [3,4]. So far, SBV has been detected in various Culicoides species such as C. obsoletus s.s., C. scoticus, C. chiopterus, C. dewulfii, C. pulicaris, or C. nubeculosus collected during summer and early autumn 2011 in Belgium, the Netherlands or Denmark [5-7]. Of head pools from Culicoides midges collected in the Netherlands throughout September and early October $20112.3 \%$ tested positive by real-time RT-PCR [5], and an infection rate of approximately $3.6 \%$

\footnotetext{
* Correspondence: martin.beer@fli.bund.de

'Equal contributors

'Institute of Diagnostic Virology, Friedrich-Loeffler-Institut, Suedufer 10, 17493

Greifswald, Insel Riems, Germany

Full list of author information is available at the end of the article
}

was estimated for Culicoides caught in the region of Antwerp (Belgium) in September 2011 [6].

However, in hibernating mosquitoes SBV was not detected which suggests that mosquitoes are not important for the persistence of SBV during winter [8]. However, their role in SBV-transmission during the period of high virus circulation is unknown.

\section{Methods}

In the present study, female mosquitoes were collected in summer and early autumn 2011 at 17 sites in Germany (Figure 1). The mosquitoes were either trapped with $\mathrm{CO}_{2}$-baited encephalitis vector surveillance (EVS) traps (BioQuip, Compton, CA) or gravid traps (GT) designed according to the CDC gravid trap model 1712 (John W. Hock Company, Gainesville, FL). Collected mosquitoes were deep-frozen transported to the laboratory and subsequently identified on chill tables according to species and sex using morphological characteristics [9]. Mosquitoes were pooled (up to 25 specimens) according to species and trapping site, placed in sterile 2-ml cryovials, and then maintained at $-70^{\circ} \mathrm{C}$ until being tested for virus RNA. The homogenization of mosquitoes was done according to Jöst et al. [10]. Total RNA was extracted using the QIAamp viral RNA mini kit (Qiagen, Hilden, Germany) according to manufacturer's 


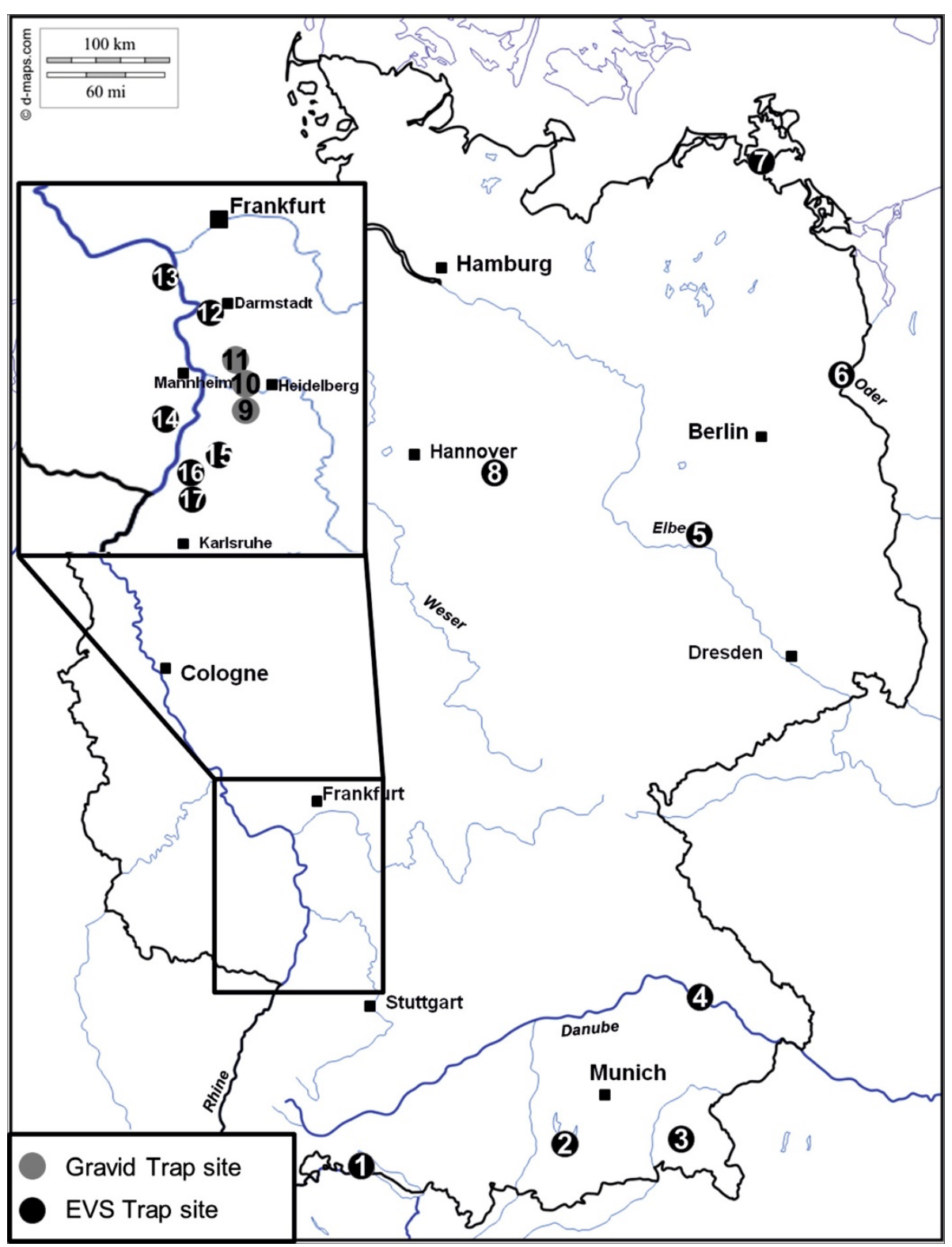

Figure 1 legend: Location of the trapping sites.

recommendation, and tested by an SBV S-segment specific real-time RT-PCR [11] which has been previously used for SBV-detection in pools of midges (up to 50 midges per pool) $[5,6,12]$.

\section{Results and discussion}

Between May and September 2011, a total of 50,708 mosquitoes were collected. The most abundant species trapped were Culex pipiens/torrentium (62\%) and Aedes vexans (24\%). The number of individuals and the species are listed in Table 1 individually for each trapping site. Most of the individuals collected in GT are gravid females, which had already taken a blood meal, making them more suitable for arbovirus surveillance. All mosquitoes collected in summer and early autumn 2011 in Germany tested negative in the SBV-specific real-time PCR. During this period, an unidentified disease, which was later identified as an infection with SBV was reported in German and Dutch dairy cattle herds [1]. From August onwards, SBV-specific antibodies were detected in domestic ruminants [13] suggesting a circulation of virus during the trapping period. After the 2011 epizootic, the seroprevalence in cattle reached nearly $100 \%$ in the focus of the affected area, and the virus had 
Table 1 Trapping sites, dates, and number of mosquitoes per species collected during the study period

\begin{tabular}{|c|c|c|c|c|c|c|c|c|c|c|c|c|c|}
\hline & $\begin{array}{l}\text { Location number } \\
\text { on map }\end{array}$ & Trapping date & $\begin{array}{l}\text { Number of } \\
\text { trappingperiods }\end{array}$ & $\begin{array}{l}\text { Trap } \\
\text { type }\end{array}$ & $\begin{array}{l}\text { Culex } \\
\text { modestus* }\end{array}$ & $\begin{array}{l}\text { Culex pipiens/ } \\
\text { torrentium }\end{array}$ & $\begin{array}{l}\text { Culex } \\
\text { territans }\end{array}$ & $\begin{array}{l}\text { Aedes } \\
\text { vexans* }\end{array}$ & $\begin{array}{l}\text { Aedes } \\
\text { cinereus* }\end{array}$ & $\begin{array}{l}\text { Aedes } \\
\text { rossicus* }\end{array}$ & $\begin{array}{l}\text { Ochlerotatus } \\
\text { annulipes* }\end{array}$ & $\begin{array}{l}\text { Ochlerotatus } \\
\text { cantans* }\end{array}$ & $\begin{array}{l}\text { Ochlerotatus } \\
\text { communis* }\end{array}$ \\
\hline Alsheim & 13 & 27-28.07.2011 & 1 & EVS & 2 & 8 & 25 & 1 & 1 & 0 & 0 & 0 & 0 \\
\hline $\begin{array}{l}\text { Lake Constance, } \\
\text { Radolfszell }\end{array}$ & 1 & 02-03.08.2011 & 1 & EVS & 0 & 71 & 0 & 33 & 22 & 0 & 0 & 0 & 0 \\
\hline Lake Chiemsee & 3 & 03-04.08.2011 & 1 & EVS & 0 & 100 & 0 & 265 & 85 & 0 & 0 & 0 & 0 \\
\hline Drömling & 8 & $18-19.08 .2011$ & 1 & EVS & 0 & 14 & 0 & 9 & 3 & 0 & 0 & 0 & 0 \\
\hline Elbe, Coswig & 5 & 15-16.08.2011 & 1 & EVS & 0 & 194 & 0 & 863 & 8 & 0 & 0 & 0 & 0 \\
\hline Greifswald & 7 & 17-18.08.2011 & 1 & EVS & 0 & 11605 & 0 & 2839 & 1629 & 4 & 13 & 433 & 16 \\
\hline Großsachsen & 10 & $\begin{array}{l}\text { May-September } \\
2011\end{array}$ & 61 & GT & 0 & 5081 & 0 & 0 & 0 & 0 & 0 & 0 & 0 \\
\hline Haßloch & 14 & $10-11.05 .2011$ & 1 & EVS & 0 & 9 & 0 & 8 & 11 & 10 & 52 & 255 & 11 \\
\hline Heidelberg & 9 & $\begin{array}{l}\text { May-September } \\
2011\end{array}$ & 41 & GT & 0 & 9581 & 0 & 0 & 0 & 0 & 0 & 1 & 0 \\
\hline Insel Rott & 17 & 26-27.07.2011 & 1 & EVS & 0 & 0 & 16 & 137 & 5 & 0 & 0 & 6 & 0 \\
\hline Isar, Schiltorn & 4 & 04-05.08.2011 & 1 & EVS & 0 & 41 & 0 & 402 & 15 & 0 & 0 & 0 & 0 \\
\hline Kühkopf & 12 & $\begin{array}{l}27-28.07 .2011 \\
10-11.08 .2011 \\
16-17.08 .2011 \\
23-24.08 .2011\end{array}$ & 4 & EVS & 0 & 208 & 0 & 6237 & 18 & 0 & 1 & 2 & 0 \\
\hline $\begin{array}{l}\text { Oder, } \\
\text { Hohenwutzen }\end{array}$ & 6 & $16-17.08 .2011$ & 1 & EVS & 0 & 1003 & 0 & 1107 & 69 & 6 & 3 & 20 & 0 \\
\hline $\begin{array}{l}\text { Osterseen, } \\
\text { Iffelsdorf }\end{array}$ & 2 & 03-04.08.2011 & 1 & EVS & 0 & 41 & 0 & 97 & 380 & 0 & 0 & 1 & 0 \\
\hline $\begin{array}{l}\text { Rußheimer } \\
\text { Altrhein }\end{array}$ & 16 & $26-27.07 .2011$ & 1 & EVS & 0 & 37 & 0 & 300 & 6 & 0 & 1 & 3 & 0 \\
\hline Waghäusel & 15 & $\begin{array}{l}\text { 07-08.06.2011, } \\
\text { 12-13.07.2011 }\end{array}$ & 2 & EVS & 0 & 32 & 6 & 0 & 0 & 19 & 45 & 168 & 0 \\
\hline Weinheim & 11 & $\begin{array}{l}\text { May-September } \\
2011\end{array}$ & 78 & GT & 0 & 3546 & 0 & 0 & 0 & 0 & 0 & 0 & 0 \\
\hline $\begin{array}{l}\text { Total no of } \\
\text { mosquitoes }\end{array}$ & & & & & 2 & 31571 & 47 & 12298 & 2252 & 39 & 115 & 889 & 27 \\
\hline
\end{tabular}


Table 1 Trapping sites, dates, and number of mosquitoes per species collected during the study period

\begin{tabular}{|c|c|c|c|c|c|c|c|c|c|c|c|c|}
\hline & $\begin{array}{l}\text { Ochlerotatus } \\
\text { geniculatus* }\end{array}$ & $\begin{array}{l}\text { Ochlerotatus } \\
\text { punctor* }\end{array}$ & $\begin{array}{l}\text { Ochlerotatus } \\
\text { rusticus }\end{array}$ & $\begin{array}{l}\text { Ochlerotatus } \\
\text { sticticus }\end{array}$ & $\begin{array}{l}\text { Ochlerotatus } \\
\text { caspius* }\end{array}$ & $\begin{array}{l}\text { Ochlerotatus } \\
\text { flavescens* }\end{array}$ & $\begin{array}{l}\text { Culiseta } \\
\text { annulata* }^{*}\end{array}$ & $\begin{array}{l}\text { Anopheles } \\
\text { claviger }\end{array}$ & $\begin{array}{l}\text { Anopheles } \\
\text { maculipennis }\end{array}$ & $\begin{array}{l}\text { Anopheles } \\
\text { plumbeus* }\end{array}$ & $\begin{array}{l}\text { Mansonia } \\
\text { richiardii* }\end{array}$ & $\begin{array}{l}\text { total no of } \\
\text { mosquitoes }\end{array}$ \\
\hline Alsheim & 0 & 0 & 0 & 0 & 0 & 0 & 13 & 0 & 6 & 0 & 0 & 56 \\
\hline $\begin{array}{l}\text { Lake } \\
\text { Constance, } \\
\text { Radolfszell }\end{array}$ & 0 & 0 & 11 & 0 & 0 & 0 & 4 & 0 & 1 & 0 & 1 & 143 \\
\hline Lake Chiemsee & 0 & 0 & 0 & 226 & 0 & 0 & 1 & 1 & 0 & 0 & 0 & 678 \\
\hline Drömling & 0 & 0 & 2 & 0 & 0 & 0 & 1 & 0 & 0 & 0 & 0 & 29 \\
\hline Elbe, Coswig & 0 & 0 & 0 & 0 & 0 & 1 & 1 & 0 & 2 & 0 & 0 & 1069 \\
\hline Greifswald & 0 & 225 & 17 & 346 & 79 & 43 & 31 & 43 & 78 & 0 & 0 & 17401 \\
\hline Großsachsen & 0 & 1 & 0 & 0 & 0 & 0 & 11 & 1 & 0 & 1 & 0 & 5095 \\
\hline Haßloch & 0 & 21 & 1702 & 7 & 0 & 0 & 6 & 2 & 9 & 0 & 0 & 2103 \\
\hline Heidelberg & 0 & 0 & 0 & 0 & 0 & 0 & 7 & 2 & 2 & 0 & 0 & 9593 \\
\hline Insel Rott & 0 & 0 & 0 & 4 & 0 & 0 & 3 & 1 & 10 & 0 & 0 & 182 \\
\hline Isar, Schiltorn & 0 & 0 & 88 & 13 & 0 & 0 & 4 & 5 & 1 & 0 & 25 & 594 \\
\hline Kühkopf & 0 & 0 & 0 & 0 & 0 & 0 & 23 & 5 & 45 & 2 & 0 & 6541 \\
\hline $\begin{array}{l}\text { Oder, } \\
\text { Hohenwutzen }\end{array}$ & 0 & 4 & 6 & 1 & 1 & 4 & 16 & 0 & 55 & 0 & 0 & 2295 \\
\hline $\begin{array}{l}\text { Osterseen, } \\
\text { Iffelsdorf }\end{array}$ & 0 & 8 & 0 & 0 & 0 & 0 & 3 & 1 & 0 & 0 & 2 & 533 \\
\hline $\begin{array}{l}\text { Rußheimer } \\
\text { Altrhein }\end{array}$ & 0 & 0 & 0 & 9 & 0 & 0 & 9 & 0 & 27 & 0 & 0 & 392 \\
\hline Waghäusel & 0 & 0 & 2 & 0 & 0 & 0 & 16 & 125 & 20 & 0 & 4 & 437 \\
\hline Weinheim & 0 & 0 & 0 & 0 & 0 & 0 & 20 & 0 & 0 & 0 & 1 & 3567 \\
\hline $\begin{array}{l}\text { Total no of } \\
\text { mosquitoes }\end{array}$ & 0 & 259 & 1828 & 606 & 80 & 48 & 169 & 186 & 256 & 3 & 33 & 50708 \\
\hline
\end{tabular}

EVS: encephalitis vector surveillance traps; GT: gravid trap; mammophilic species are marked with * according to Becker et al. [16].

Total numbers of mosquitos are printed in bold type. 
spread very rapidly over large parts of Europe [14,15]. SBV was even detected in Culicoides midges caught in Denmark in October or in Italy between September and November 2011 (reviewed in [14]). In the German federal state Rhineland-Palatinate, the seroprevalence in cattle was approximately $80 \%$ (95\% confidence interval (CI) $67.67-89.22 \%)$ after the 2011 epizootic, and in BadenWuerttemberg it was about 32\% (95\% CI 22.23 - 44.10\%) [14], the trapping sites 9 to 17, where more than half of the mosquitoes were collected, are located in the border region of both federal states. Despite this very high prevalence in the ruminant hosts and the thereby presumably considerable virus circulation, none of the mosquitoes collected in the present study tested positive by the SBV-specific real-time RT-PCR. However, approximately one third of the tested mosquitoes were caught in Mecklenburg-Pomerania (trapping site 7), a region with a seroprevalence of only about $2 \%$ (95\% CI $0.06-12.29 \%)$ in cattle [14].

In Australia, Asia or Africa, Simbu viruses can be isolated from local mosquitoes [3,4]. Since SBV is the first European member of the Simbu serogroup, species potentially involved in transmission in Europe cannot be deduced from closely related viruses. However, several mosquito-borne mammal-associated orthobunyaviruses of other serogroups such as Ťahyňa virus, Inkoo virus (both California serogroup) or Batai virus (Bunyamwera group) have been documented in various western European countries [17]. Of these, Ťahyňa virus is most often isolated from Aedes vexans, which was the second most common species trapped in the present study, but also from other culicine mosquitoes. The principal vector for Batai virus in Europe are zoophilic mosquitoes such as Anopheles maculipennis s.l., Anopheles claviger, Ochlerotatus punctor and Ochlerotatus communis, among others [18]. All of these species were collected in the present study and tested for the presence of SBV.

Despite reported symptoms of the disease in susceptible animals during the trapping period and a high seroprevalence after the first vector season, none of the collected mosquitoes tested positive in the SBV-specific real-time RT-PCR. Considering the detection of viral RNA in biting midges in regions with a much lower seroprevalence in ruminants, in Denmark even before clinical signs were observed or virus was detected in domestic animals [19], mosquitoes most likely play only a negligible, if any, role in SBV transmission.

\section{Abbreviations}

SBV: Schmallenberg virus; EVS: Encephalitis vector surveillance; GT: Gravid trap.

\section{Competing interests}

The authors have no financial, personal, or professional interests that inappropriately influenced this paper.

\section{Authors' contributions}

Conceived and designed the experiments: NB, JS, MB. Performed the experiments: HJ. Analyzed the data: KW HJ. Drafted the manuscript: KW JH. All authors read and approved the final manuscript.

\section{Acknowledgments}

Alexandra Bialonski provided excellent technical assistance and Christina Czajka's help during the trapping of the mosquitoes is gratefully acknowledged.

\section{Author details}

${ }^{1}$ Institute of Diagnostic Virology, Friedrich-Loeffler-Institut, Suedufer 10, 17493 Greifswald, Insel Riems, Germany. ${ }^{2}$ Bernhard Nocht Institute for Tropical Medicine, Department of Virology, Bernhard-Nocht-Straße 74, 20359 Hamburg, Germany. ${ }^{3}$ German Centre for Infection Research (DZIF), partner site Hamburg-Luebeck-Borstel, Hamburg, Germany. ${ }^{4}$ German Mosquito Control Association (KABS), Waldsee, Germany.

Received: 27 June 2014 Accepted: 5 August 2014

Published: 29 August 2014

\section{References}

1. Hoffmann B, Scheuch M, Höper D, Jungblut R, Holsteg M, Schirrmeier $H_{\text {, }}$ Eschbaumer M, Goller KV, Wernike K, Fischer M, Breithaupt A, Mettenleiter T, Beer M: Novel orthobunyavirus in cattle, Europe, 2011. Emerg Infect Dis 2012, 18(3):469-472.

2. Beer M, Conraths FJ, van der Poel WH: 'Schmallenberg virus' - a novel orthobunyavirus emerging in Europe. Epidemiol Infect 2013, 141(1):1-8.

3. Elliott RM, Blakqori G: Molecular biology of orthobunyaviruses. In Bunyaviridae: Molecular and Cellular Biology. Edited by Plyusnin A, Elliott RM. Norfolk, UK: Caister Academic Press; 2011:1-39.

4. Saeed MF, Li L, Wang H, Weaver SC, Barrett AD: Phylogeny of the Simbu serogroup of the genus Bunyavirus. J Gen Virol 2001, 82(Pt 9):2173-2181.

5. Elbers AR, Meiswinkel $R$, van Weezep $E$, van Oldruitenborgh-Oosterbaan MM S, Kooi EA: Schmallenberg Virus in Culicoides spp. Biting Midges, the Netherlands, 2011. Emerg Infect Dis 2013, 19(1):106-109.

6. De Regge N, Deblauwe I, De Deken R, Vantieghem P, Madder M, Geysen D, Smeets F, Losson B, van den Berg T, Cay AB: Detection of Schmallenberg virus in different Culicoides spp. by real-time RT-PCR. Transboundary and emerging diseases 2012, 59(6):471-475.

7. Rasmussen LD, Kristensen B, Kirkeby C, Rasmussen TB, Belsham GJ, Bodker R, Bøtner A: Culicoids as vectors of schmallenberg virus. Emerg Infect Dis 2012, 18(7):1204-1206.

8. Scholte EJ, Mars MH, Braks M, DENH W, Ibanez-Justicia A, Koopmans M, Koenraadt JC ADEV, Reusken C: No evidence for the persistence of Schmallenberg virus in overwintering mosquitoes. Med Vet Entomol 2013, 28(1):110-115.

9. Becker N, Petric D, Zgomba M, Boase C, Dahl C, Lane J, Kaiser A: Mosquitoes and their control. 1st edition. New York, NY: Kluwer; 2003.

10. Jöst H, Bialonski A, Storch V, Gunther S, Becker N, Schmidt-Chanasit J: Isolation and phylogenetic analysis of Sindbis viruses from mosquitoes in Germany. J Clin Microbiol 2010, 48(5):1900-1903.

11. Bilk S, Schulze C, Fischer M, Beer M, Hlinak A, Hoffmann B: Organ distribution of Schmallenberg virus RNA in malformed newborns. Vet Microbiol 2012, 159(1-2):236-238.

12. Elbers $A R$, Meiswinkel $R$, van Weezep $E$, Kooi EA, van der Poel WH: Schmallenberg Virus in Culicoides Biting Midges in the Netherlands in 2012. Transboundary and emerging diseases 2014, doi:10.1111/tbed.12128.

13. Veldhuis AM, van Schaik $G$, Vellema P, Elbers AR, Bouwstra R, van der Heijden HM, Mars MH: Schmallenberg virus epidemic in the Netherlands: Spatiotemporal introduction in 2011 and seroprevalence in ruminants. Prev Vet Med 2013, 112(1-2):35-47.

14. Wernike K, Conraths F, Zanella G, Granzow H, Gache K, Schirrmeier H, Valas S, Staubach C, Marianneau P, Kraatz F, Höreth-Böntgen D, Reimann I, Zientara S, Beer M: Schmallenberg virus-Two years of experiences. Prev Vet Med 2014, doi:10.1016/j.

15. EFSA: "Schmallenberg" virus: analysis of the epidemiological data (May 2013). In EFSA Supporting Publications 2013 EN-3429; http://www.efsa.europa.eu/de/ supporting/doc/429e.pdf; accessed 15/07/2013 2013.

16. Becker N, Kruger A, Kuhn C, Plenge-Bonig A, Thomas SM, Schmidt-Chanasit J, Tannich E: [Mosquitoes as vectors for exotic pathogens in Germany]. Bundesgesundhbl. Gesundheitsforsch. Gesundheitsschutz 2014, 57(5):531-540. 
17. Lundström JO: Mosquito-borne viruses in western Europe: a review. Journal of vector ecology: journal of the Society for Vector Ecology 1999, 24(1):1-39.

18. Hubalek Z: Mosquito-borne viruses in Europe. Parasitol Res 2008, 103(Suppl 1):S29-S43.

19. Rasmussen LD, Kirkeby C, Bodker R, Kristensen B, Rasmussen TB, Belsham GJ, Bøtner A: Rapid spread of Schmallenberg Virus-infected Biting Midges (Culicoides spp.) across Denmark in 2012. Transboundary and Emerging Diseases 2014, 61(1):12-16.

doi:10.1186/1756-3305-7-402

Cite this article as: Wernike et al:: Lack of evidence for the presence of Schmallenberg virus in mosquitoes in Germany, 2011. Parasites \& Vectors 2014 7:402.

\section{Submit your next manuscript to BioMed Central} and take full advantage of:

- Convenient online submission

- Thorough peer review

- No space constraints or color figure charges

- Immediate publication on acceptance

- Inclusion in PubMed, CAS, Scopus and Google Scholar

- Research which is freely available for redistribution

Submit your manuscript at www.biomedcentral.com/submit 